Editorial

\title{
Constructed Wetlands for Water Treatment: New Developments
}

\author{
Pedro N. Carvalho, Carlos A. Arias and Hans Brix * \\ Department of Bioscience, Aarhus University, 8000C Aarhus, Denmark; pedro.carvalho@bios.au.dk (P.N.C.); \\ carlos.arias@bios.au.dk (C.A.A.) \\ * Correspondence: hans.brix@bios.au.dk \\ Academic Editor: Arjen Y. Hoekstra \\ Received: 24 April 2017; Accepted: 31 May 2017; Published: 2 June 2017
}

\begin{abstract}
Constructed wetlands (CWs) are currently regarded as established eco-technologies to treat water pollution. Although considered near-natural systems, they are totally engineered solutions for which research has been actively developed over the past decades. This paper provides a brief meta-analysis on the latest scientific publications in the field and an overview of the special issue focused on the new developments in the use of CWs for water treatment. The selected papers cover a wide range of relevant developments in the field, including the use of different CW system designs, the capacity to treat different types of pollutants, and studies aiming at getting a better understanding of the treatment processes in CWs.
\end{abstract}

Keywords: treatment wetland; constructed wetland; wastewater treatment; water pollution; eco-technology; decentralized systems

\section{Introduction}

The historical use of wetlands for water pollution control can be traced to the ancient Chinese and Egyptian civilizations [1]. As long as humans have discharged sewage into the environment, wetlands have more or less intentionally been involved in the cleaning of the wastewater. In the previous century, artificial wetlands started to be constructed for the purpose of treating different kinds of wastewater, and in the last decades, constructed wetlands (CWs) have been developed into fully engineered systems. Nowadays, CWs are often defined as green, sustainable, low-cost, robust, and efficient engineered systems for water treatment, with added ecosystem services.

Constructed wetland, as a name, can be found in the Web of Science Core Collection (Bibliography search details: TOPIC $=\left(\right.$ "constructed wetland $\left.{ }^{* \prime \prime}\right)$, Timespan $=1900-2016$, Indexes $=$ SCI-EXPANDED, SSCI, A\&HCI, CPCI-S, CPCI-SSH, ESCI), and was first used in a scientific publication in 1989 [2]. The first studies in the US addressed the use of CWs as an inexpensive alternative to conventional acid mine water treatment $[3,4]$. The first studies from Europe can be found in the book covering the Proceedings of the International Conference on the Use of Constructed Wetlands in Water Pollution Control, which was held in Cambridge, UK, in September 1990. However, the usage of this type of eco-technology can be bibliographically traced back to the 1980s-90s under a diverse spectrum of names: "constructed wetland", "artificial wetland", "reed bed", "helophyte bed", "hydrophyte bed", "macrophyte bed", or "root zone method" (Figure 1). "Constructed wetland" is currently the most commonly used name, followed by "treatment wetland", "reed bed", and "artificial wetland" (Figure 1). 


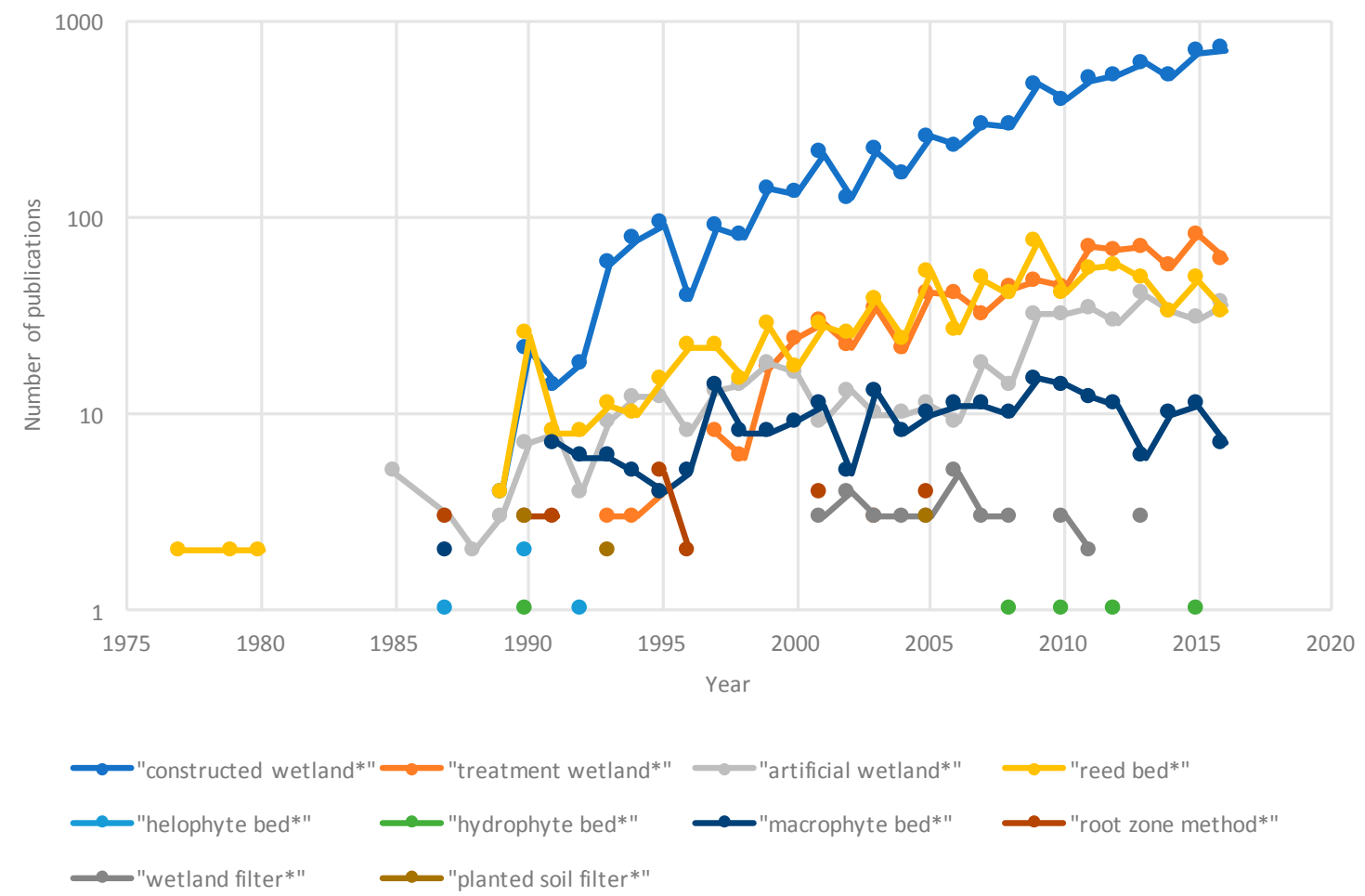

Figure 1. Number of publications retrieved in March 2017 from the Web of Science Core Collection for the different constructed wetland technology names: TOPIC $=\left(\right.$ "names" $\left.{ }^{*}\right)$, Timespan $=1900-2016$, Indexes = SCI-EXPANDED, SSCI, A\&HCI, CPCI-S, CPCI-SSH, ESCI.

The number of publications retrieved by the Web of Science in March 2017 (Bibliography search details: TOPIC $=\left(\right.$ "constructed wetland $\left.d^{* \prime}\right)$ OR TOPIC $=\left(\right.$ "treatment wetland $\left.{ }^{* \prime \prime}\right)$ OR TOPIC $=($ "artificial wetland $\left.{ }^{* \prime}\right)$ OR TOPIC $=\left(\right.$ "reed bed $\left.{ }^{* \prime \prime}\right)$ OR TOPIC $=\left(\right.$ "macrophyte bed $\left.{ }^{* \prime \prime}\right)$, Timespan $=1900-2016$, Indexes = SCI-EXPANDED, SSCI, A\&HCI, CPCI-S, CPCI-SSH, ESCI) was 8217 (from the first reports until 2016), when using queries with the most common CW names ("constructed wetland", "treatment wetland", "artificial wetland", "reed bed", and "macrophyte bed"). Applying a filter to identify the last 3 years of publication (timespan $=2014-2016$ ), the number of works retrieved was 2124 (Bibliography search details: TOPIC $=\left(\right.$ "constructed wetland $\left.{ }^{* \prime \prime}\right)$ OR TOPIC $=($ "treatment wetland" $)$ OR TOPIC $=\left(\right.$ "artificial wetland $\left.{ }^{* \prime}\right)$ OR TOPIC $=\left(\right.$ "reed bed $\left.{ }^{* \prime \prime}\right)$ OR TOPIC $=\left(\right.$ "macrophyte bed $\left.{ }^{* \prime \prime}\right)$, Timespan $=$ 2014-2016, Indexes = SCI-EXPANDED, SSCI, A\&HCI, CPCI-S, CPCI-SSH, ESCI).

Figure 2 shows that from these most recent 2124 publications, the majority are scientific articles $(88 \%)$, followed by conference proceedings (10\%), and reviews (5\%). In fact, 107 review papers have been published in the past 3 years focusing on CWs. Geographically, the following countries have contributed the majority of the published works: People's Republic of China (33\%), USA (18\%), and Europe (>20\%).

The second step, performed to summarize the publication trends for the past 3 years, was to refine the search by adding a secondary term " $Y$ " within the 2124 works previously retrieved (Bibliography search details: TOPIC $=\left(\right.$ "constructed wetland $\left.{ }^{* \prime}\right)$ OR TOPIC $=($ "treatment wetland" $)$ OR TOPIC $=\left(\right.$ "artificial wetland $\left.{ }^{* \prime \prime}\right)$ OR TOPIC $=\left(\right.$ "reed bed $\left.{ }^{* \prime \prime}\right)$ OR TOPIC $=($ "macrophyte bed" $)$, Timespan $=$ 2014-2016, Indexes = SCI-EXPANDED, SSCI, A\&HCI, CPCI-S, CPCI-SSH, ESCI). From the number of publications categorized by pollutant type, it can be seen that typical organic pollutants (COD, carbon organic load), nitrogen (ammonia and nitrate), and solids have been the main focus for recent research (Table 1). There are considerably fewer studies on pathogens than for other typical pollutants. 


\section{Document Types}

- Article " Proceedings Paper " Review " Editorial Material " Meeting Abstract " Correction - Book Chapter

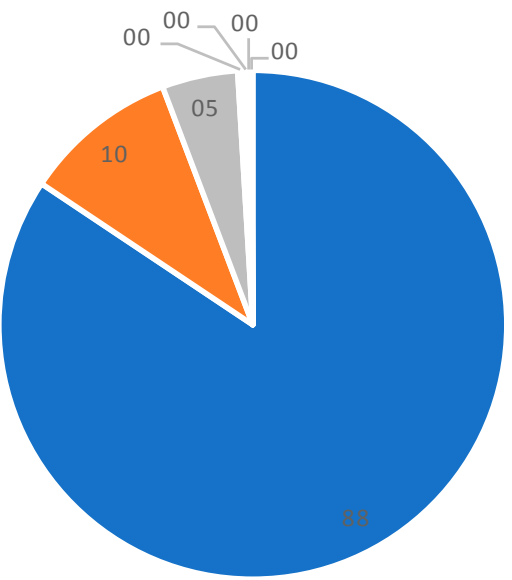

(a)

\section{Countries/Territories}

- Peoples R China " USA = France " Canada " Australia " Germany - Spain " Italy " England " India - Others

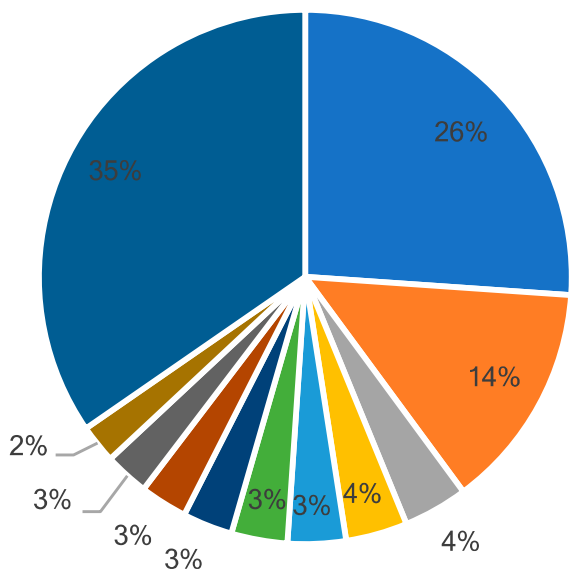

(b)

Figure 2. Publications organized according to (a) Document Type and (b) Country, retrieved in March 2017 from the Web of Science for published works from 2014 to 2016: TOPIC = ("constructed wetland *") OR TOPIC = ("treatment wetland *") OR TOPIC $=($ "artificial wetland *") OR TOPIC $=($ "reed bed *" $)$ OR TOPIC $=\left(\right.$ "macrophyte bed $\left.{ }^{* \prime \prime}\right)$, Timespan = 2014-2016, Indexes = SCI-EXPANDED, SSCI, A\&HCI, CPCI-S, CPCI-SSH, ESCI. 
Table 1. Publications retrieved in March 2017 after the search was refined by adding a secondary term " $Y^{\prime \prime}$ within the 2124 works previously retrieved (Bibliography search details: TOPIC $=\left(\right.$ "constructed wetland $\left.{ }^{* \prime}\right)$ OR TOPIC $=($ "treatment wetland" $)$ OR TOPIC $=($ "artificial wetland" $)$ OR TOPIC $=($ "reed bed" $)$ OR TOPIC $=$ ("macrophyte bed"), Timespan = 2014-2016, Indexes = SCI-EXPANDED, SSCI, A\&HCI, CPCI-S, CPCI-SSH, ESCI). The number of publications for each of the refined searches were organized according to pollutant, size, design, application, and other keywords, and represented as the percentage (\%) of the 2124 publications covering the period 2014-2016.

\begin{tabular}{|c|c|c|c|c|c|c|c|c|c|}
\hline \multicolumn{10}{|l|}{ Refined by: } \\
\hline Pollutants & $\%$ of 2124 & Size & $\%$ of 2124 & Design & $\%$ of 2124 & Application & $\%$ of 2124 & Other Keywords & $\%$ of 2124 \\
\hline carbon & 16.1 & microcosm* & 4.7 & \multirow{2}{*}{$\begin{array}{r}\text { surface flow } \\
\text { horizontal subsurface } \\
\text { flow }\end{array}$} & 16.1 & \multirow{3}{*}{$\begin{array}{r}\text { wastewater } \\
\text { artificial } \\
\text { wastewater } \\
\text { industrial } \\
\text { wastewater }\end{array}$} & 42.2 & plants & 48.4 \\
\hline organic load & 8.4 & mesocosm* & 4.2 & & 13.8 & & 3.2 & media & 11.7 \\
\hline $\begin{array}{r}\text { chemical oxygen } \\
\text { demand (COD) }\end{array}$ & 16.4 & laboratory scale & 3.8 & vertical flow & 11.5 & & 3.2 & substrate & 9.1 \\
\hline solids & 11.6 & pilot scale & 9.3 & floating & 4.4 & $\begin{array}{r}\text { domestic } \\
\text { wastewater }\end{array}$ & 9.2 & season & 7.3 \\
\hline phosphorous & 2.4 & full scale & 4.4 & hybrid system* & 4.0 & urban wastewater & 4.1 & operation mode & 0.6 \\
\hline nitrogen & 38.1 & & & intensified system ${ }^{*}$ & 0.7 & stormwater & 7.3 & latitude & 0.1 \\
\hline ammonia & 9.3 & & & forced aeration & 0.2 & surface water & 22.8 & insect* & 0.5 \\
\hline nitrate & 12.9 & & & intermittent aeration & 1.5 & run-off & 0.5 & microbial communit* & 8.4 \\
\hline pathogen* & 3.1 & & & tidal flow & 1.6 & agriculture & 4.0 & microbial process* & 5.6 \\
\hline organic pollutant* & 7.7 & & & fill and drain & 0.3 & river ${ }^{*}$ & 14.8 & microorganism* & 5.5 \\
\hline persistent pollutant & 0.3 & & & restoration & 6.1 & sludge & 9.7 & gas emission & 3.5 \\
\hline $\begin{array}{r}\text { emerging } \\
\text { contaminant }\end{array}$ & 2.0 & & & french system ${ }^{*}$ & 0.6 & $\begin{array}{r}\text { sustainable urban } \\
\text { drainage systems } \\
\text { (SUD)* }\end{array}$ & 0.4 & ecological impact & 1.8 \\
\hline $\begin{array}{r}\text { pharmaceutical }^{*} \text { and } \\
\text { personal care } \\
\text { product }^{*}\end{array}$ & 2.3 & & & buffer strip* & 1.1 & $\begin{array}{r}\text { combined sewer } \\
\text { overflow (CSO) }\end{array}$ & 0.3 & ecosystems service* & 3.4 \\
\hline pesticide* & 2.4 & & & fuel cell ${ }^{*}$ & 2.4 & oil production & 0.4 & climate adaptation & 0.2 \\
\hline nanoparticle* & 0.7 & & & & & & & water reuse & 6.4 \\
\hline \multirow[t]{2}{*}{ metal $^{*}$} & 13.4 & & & & & & & modelling & 18.1 \\
\hline & & & & & & & & $\begin{array}{l}\text { advanced oxidation } \\
\text { process* }\end{array}$ & 0.8 \\
\hline
\end{tabular}

Note: The asterisk as " $\mathrm{Y}^{* \prime}$ was to broaden the search by finding words that start with the same letters, allowing variations of a term. 
Interestingly, with respect to inorganic contaminants, nanoparticles are beginning to be studied in CWs. Regarding organic micropollutants, in contrast with the lower number of studies on persistent contaminants (persistent organic pollutants (POPs), polycyclic aromatic hydrocarbons (PAHs), polychlorinated biphenyls (PCBs), organochlorine pesticides (OCPs)), emerging contaminants such as pharmaceutical and personal care products (PPCPs) and pesticides seem to be attracting increasing attention. CW size is generally not identified in the title and keywords, as CW size is typically not a studied factor in itself. When analyzing studies on CW design, surface flow (SF), horizontal subsurface flow (HSSF) and vertical flow (VF) systems lead the recent trends in research. Notably, the more recent floating bed designs account for the same percentage as hybrid (HSSF $\Leftrightarrow$ VF) systems.

In the past 3 years, intensified CW designs, such as systems with forced aeration, intermittent aeration, or tidal flow, have attracted equal research interest to the French systems and buffer strips. Additionally, publications addressing wetland restoration represent an appreciable amount of the scientific production. The integration of microbial fuel cells into CWs is a recent topic with a considerable number of publications. Regarding areas of CW application, the treatments of wastewater, storm water, surface water, and river water are the most notable. Sludge dewatering and mineralization have also been receiving some attention. Combined sewage systems-typically identified as sustainable urban drainage system (SUDS) or combined sewage overflow (CSO)-have a relatively low publication frequency, similar to that of run-off. Other relevant topics/keywords include plants, media/substrate, and modelling. Gas emissions, ecological impact, ecosystems services, and climate adaptation have all been explored within CW research, although they fall outside of the direct scope of water treatment. The combination of CWs and advanced oxidation processes is starting to be studied.

By summarizing the focus of publications and the contributions presented at some of the most relevant symposia in the CW field (IWA 14th ICWS 2014 Shanghai, WETPOL 2015 York, and IWA 15th ICWS 2016 Gdansk) over the last 3 years, we identify the following new trends:

- Different intensification techniques and operational modes are being explored that go beyond the first forced aeration system [5]. More research groups are working with CW bed aeration, exploring intermittent aeration or combining it with tidal flows or fill-and-drain variations.

- Contaminants of emerging concern (PPCPs, pesticides, nanoparticles, etc.) are expected to continue to be "hot topics" for years to come. Although research on PPCPs and pesticides has been conducted for the last 10 years, it remains a challenging area. There are several families of compounds that have barely been addressed (illicit drugs, flame retardants, and plasticizers, among others). Research on nanoparticle effects and their fate in CWs is only starting now.

- Water reuse and nutrient and energy recycling are the new paradigms that the $\mathrm{CW}$ community is starting to address, reflecting the main trends in the wider water sector and complementing the existing research on ecosystem services. Water reuse research has started to address the combination of advanced oxidation processes combined with CWs to ensure compliance with the required legislation of discharge-reuse standards.

- The integration of microbial fuel cell concepts into CW designs is starting to be visible. The use of bioelectrochemical systems and the related microbial electrolysis cell, where electric current is used to achieve improved pollutants degradation, is a new and very prosperous line of research.

However, we identify some challenges:

- Hybrid systems will need to become more complex and diverse to incorporate different geographical/market needs as well as new technological developments.

- Emerging contaminant research is limited by the costs and access to state-of-the-art analytical equipment. In addition, it will be dependent on parallel advances in the elucidation of transformation products and the toxicology of both parent and transformation products. 
- Water reuse development will need to be linked with research on pathogens and fecal contamination removal as well as on micropollutant removal—especially in the critical areas of antibiotics and antibiotic resistance.

- Understanding the microbial community and plant-microbe interactions, although facilitated by more affordable and easily accessible omics analysis technology, has also resulted in the generation of huge amounts of complex data sets that require experienced microbiologists and the integration of bio-engineering.

\section{This Special Issue}

Researchers and practitioners have been working on various approaches for reducing CW area requirements and increasing the capacity of traditional CW systems. CWs are also being tested for their capacity to tackle new challenges, such as the removal of special/emerging/recalcitrant pollutants, as well as many types of industrial wastewaters. Additionally, our mechanistic understanding of the processes occurring inside the CW "black-box" has advanced significantly in recent years. This Special Issue of Water compiles some of the latest advances in CW technology, contributing to the further development and dissemination of this reliable and robust water treatment solution.

Weber K.P. [6] looks into the past, present, and future of microbial community assessment in the field of CWs. This review covers a meta-analysis on microbial community assessment methodology and its applications for focused pollutant degradation, system size and design, and regional trends. Future horizons indicate that the combination of high-powered metagenomic sequencing, the development and utilization of functional assays such as DNA microarrays, and community level physiological profiling, in concert with activity assessment, enumeration, and newly-implemented stable isotope methodologies are moving the knowledge on CWs beyond the black-box paradigm [6].

Kadlec R.H. [7] reviews the application of large ( $>40 \mathrm{ha}) \mathrm{CWs}$ for phosphorous control. This overview covers 37 systems in operation, resulting in 357 wetland-years of information on P removal. The focus of the work is on total phosphorus performance measures, rather than on mechanistic approaches. Concentration reduction (median $71 \%$ ) or removal rate coefficients (median $12.5 \mathrm{~m} \cdot$ year $^{-1}$ ) were determined for the entire period on record for all studied large systems. The type of vegetation community was found to affect the performance measures, and the hydraulics of large systems were found to differ considerably from those of smaller CWs. The socio-economic aspects of wetland construction were found to be enhanced at the large-scale. Although transferability remains an issue, the author proposes a couple of mathematical models calibrated to data from large P-treatment wetlands [7].

Langergraber G. [8] reviews the existent process-based models for subsurface flow treatment wetlands. The two most advanced models using multi-component biokinetics-HYDRUS Wetland Module and BIO-PORE-are described, and typical simulation results for vertical flow systems are presented. Further, experiences and challenges using process-based wetland models (water flow, transport, biokinetic, plant and clogging models) are discussed. It is concluded that although the interest in modelling CW processes has increased over the last decades, the available simulation tools for the wider user are still complicated and difficult to run, posing an obstacle to the field [8].

Brix H. [9] presents an overview of the use of sludge treatment reed beds (STRBs) for sludge dewatering and mineralization. The design and operation requirements of STRBs are described, and their performance is summarized for final dry matter content, degree of mineralization, emission of greenhouse gases, and degradation of micro-pollutants. Although STRB application has been limited to northern Europe, it is identified as a technology with application potential in other climatic regions, as well as for several types of sludge [9].

The incorporation of forced aeration in CWs is one of the latest trends in CW design, and is highlighted by the submission of four publications on this topic for the present issue [10-13]. He et al. [10] made use of aeration to overcome the limitations of high alkaline stripped effluent. Two intensification strategies-(i) intermittent aeration and (ii) effluent recirculation-are identified to 
enhance the performance of nitrogen depuration. Results revealed that the combination of recirculation with intermittent aeration improved total nitrogen removal by up to $71 \%$, while ammonia volatilization from the wetlands under high alkaline conditions only contributed to $3 \%$ of the total removed ammonium [10]. Butterworth et al. [11] compare the performance of four full-scale aerated horizontal flow CWs in the UK which received high and variable ammonia loading rates $\left(0.1\right.$ and $13.0 \mathrm{~g} \mathrm{NH}_{4}{ }^{+}-\mathrm{N}$ $\mathrm{m}^{-2} \mathrm{~d}^{-1}$ ). This study demonstrates the efficacy of the technology, where ammonium removal is required on small sites (effluent concentrations $<3 \mathrm{mg} \mathrm{NH}_{4}{ }^{+}-\mathrm{N} \mathrm{L}^{-1}$ ) receiving high and variable flow rates, while maintaining the adequate removal of organics and solids. The mixing patterns in the bed demonstrated a decrease in volumetric efficiency over time; thus, no significant benefit to the long-term hydraulics of the systems was found [11]. Boog et al. [12] report the first experimental trial using a simple wind-driven air pump to replace the conventional electric air blowers of an aerated horizontal subsurface flow $\mathrm{CW}$. The wind-driven aeration system was functional, but treatment performance was lower compared with prior continuous aeration. Inconsistent wind speeds at the site were indicated to result in insufficient pressure within the aeration manifold and consequently affect the air supply to the wetland bed. Several practical considerations are discussed for future advances in the topic [12]. Zhai et al. [13] report on the operation of a full-scale hybrid CW consisting of a continuously aerated vertical-baffled flow wetlands (VBFWs) followed by horizontal subsurface flow wetlands (HSFWs), used to improve nutrient removal from sewage wastewater. This novel proposed hybrid CW design was able to achieve relatively good pollutant removal rates, including nutrient removal (total nitrogen (TN), and total phosphorous (TP), approximately 65\%). Interestingly, despite the same aeration strategy and almost similar aerobic conditions throughout the year, nutrient removal rates were significantly lower in winter than summer [13].

Cui et al. [14] applied a first-order kinetic model to estimate the area-based constant and temperature coefficient of $\mathrm{N}$ removal by a horizontal subsurface constructed wetland (HSSF-CW) in Beijing, China, for two years. Furthermore, the modeled parameters and the relationships between the area-based constant and influencing factors (such as temperature, pollution load, and DO) were assessed [14].

Bai et al. [15] applied a groundwater modeling package (MODFLOW) to optimize three design parameters (length-to-width ratio, inlet/outlet-to-length ratio, and substrate size configuration) in horizontal subsurface flow CWs by comparing modeled data with data from three pilot-scale systems. They conclude that a multilayer configuration with increasing hydraulic conductivity from the surface to bottom layers moderately reduces short-circuiting and dead zones, significantly improving removal performance compared with the traditional monolayer configuration [14].

Lenhart et al. [16] developed a new edge-of-field treatment wetland to remove nitrate-nitrogen and enhance phosphorus removal from agricultural drainage water. A mass balance approach with DRAINMOD was used to predict nitrate removal and was further compared with the real data obtained from a designed and installed wetland covering 0.10 ha. The designed wetland was effective in removing nitrate, but the hydrologic inputs, hydraulics, and flow-pathways were slightly different than predicted. Phosphorus removal was calculated to be approximately $76 \%$ over three years, and was concluded to be enhanced by plant harvest [16].

Oopkaup et al. [17] present a deep insight into the dynamics of bacterial community abundance and structure in a newly-established unplanted horizontal subsurface flow (HSSF) mesocosm (from a broader experimental plant). High-throughput sequencing and $\mathrm{QPCR}$ analysis were successfully applied to determine the bacterial community structure and abundance, respectively. Moreover, the factors affecting bacterial community composition were screened through the distance-based regression analysis, and denitrification potential and the relationship between treatment efficiency and bacterial community structure were assessed. Based on the obtained data, the authors suggest that nitrogen removal in their system consists of two main pathways: (i) heterotrophic nitrification, which is coupled with aerobic denitrification and mediated by mixotrophic nitrite-oxidizers; and (ii) anaerobic denitrification [17]. 
Bôto et al. [18] used CW microcosms to evaluate CWs for the removal of antibiotics (enrofloxacin and oxytetracycline) and antibiotic-resistant bacteria from saline aquaculture wastewaters. The systems were able to remove the antibiotics and antibiotic-resistant bacteria, and reduce wastewater toxicity. In addition, no impact of the antibiotic presence was observed on the removal of nutrients, organic matter, and metal, with percentages being similar between exposed and unexposed microcosms [18].

Walton et al. [19] studied the effects of two hydrological regimens (early season raised water level and ambient water level) on the sustainability of the emergent plant Bolboschoenus maritimus, water quality performance, and reduction of mosquito populations in 0.09 ha free water surface (FWS) treatment wetlands over a two-year period. In the test cells, the bulrush expanded rapidly following transplantation, but stem densities declined rapidly following the colonization of competitively superior large emergent plant species in the second year of the study. Mosquito production was not detected during the summer and autumn of the first year, when B. maritimus was the only macrophyte present in the test cells, but increased during the second year. The hydrological regime did not significantly affect water quality performance (removal of nitrogen, phosphorus, and chemical oxygen demand) in the wetlands. The findings are discussed in relation to vegetation management and integrated mosquito management strategies [19].

Acknowledgments: Thanks to all authors that contributed to this special issue, to the reviewers for the very constructive feedback provided, and to the Water editorial board for the smooth management of the process.

Conflicts of Interest: The authors declare no conflict of interest.

\section{References}

1. Brix, H. Use of constructed wetlands in water-pollution control-Historical development, present status, and future perspectives. Water Sci. Technol. 1994, 30, 209-223.

2. Snoddy, E.L.; Cooney, J.C. Insecticides for Insect Pest-Control in Constructed Wetlands for Waste-Water Treatment-A Dilemma. In Proceedings of the National Pesticide Conference, Richmond, VA, USA, 11-12 May 1989; pp. 440-443.

3. Girts, M.A.; Kleinmann, R.L.P. Constructed Wetlands for Treatment of Acid Mine Drainage: A Preliminary Review. In Proceedings of the 1986 Symposium on Mining, Hydrology, Sedimentology and Reclamation, Lexington, KY, USA, 8-11 December 1986; University of Kentucky, Office of Engineering Services: Lexington, KY, USA, 1986.; pp. 165-171.

4. Natural systems vs. The 'black box'. BioCycle 1989, 30, 68-69.

5. Wallace, S. Advanced designs for constructed wetlands. BioCycle 2001, 42, 40.

6. Weber, P.K. Microbial community assessment in wetlands for water pollution control: Past, present, and future outlook. Water 2016, 8, 503. [CrossRef]

7. Kadlec, H.R. Large constructed wetlands for phosphorus control: A review. Water 2016, 8, 243. [CrossRef]

8. Langergraber, G. Applying process-based models for subsurface flow treatment wetlands: Recent developments and challenges. Water 2017, 9, 5. [CrossRef]

9. Brix, H. Sludge dewatering and mineralization in sludge treatment reed beds. Water 2017, 9, 5. [CrossRef]

10. He, K.; Lv, T.; Wu, S.; Guo, L.; Ajmal, Z.; Luo, H.; Dong, R. Treatment of alkaline stripped effluent in aerated constructed wetlands: Feasibility evaluation and performance enhancement. Water 2016, 8, 386. [CrossRef]

11. Butterworth, E.; Richards, A.; Jones, M.; Mansi, G.; Ranieri, E.; Dotro, G.; Jefferson, B. Performance of four full-scale artificially aerated horizontal flow constructed wetlands for domestic wastewater treatment. Water 2016, 8, 365. [CrossRef]

12. Boog, J.; Nivala, J.; Aubron, T.; Wallace, S.; Sullivan, C.; Van Afferden, M.; Müller, A.R. Treatment wetland aeration without electricity? Lessons learned from the first experiment using a wind-driven air pump. Water 2016, 8, 502. [CrossRef]

13. Zhai, J.; Xiao, J.; Rahaman, H.M.; John, Y.; Xiao, J. Seasonal variation of nutrient removal in a full-scale artificial aerated hybrid constructed wetland. Water 2016, 8, 551. [CrossRef]

14. Cui, L.; Li, W.; Zhang, Y.; Wei, J.; Lei, Y.; Zhang, M.; Pan, X.; Zhao, X.; Li, K.; Ma, W. Nitrogen removal in a horizontal subsurface flow constructed wetland estimated using the first-order kinetic model. Water 2016, 8, 514. [CrossRef] 
15. Bai, S.; Lv, T.; Ding, Y.; Li, X.; You, S.; Xie, Q.; Brix, H. Multilayer substrate configuration enhances removal efficiency of pollutants in constructed wetlands. Water 2016, 8, 552. [CrossRef]

16. Lenhart, C.; Gordon, B.; Gamble, J.; Current, D.; Ross, N.; Herring, L.; Nieber, J.; Peterson, H. Design and hydrologic performance of a tile drainage treatment wetland in minnesota, USA. Water 2016, 8, 549. [CrossRef]

17. Oopkaup, K.; Truu, M.; Nõlvak, H.; Ligi, T.; Preem, J.-K.; Mander, Ü.; Truu, J. Dynamics of bacterial community abundance and structure in horizontal subsurface flow wetland mesocosms treating municipal wastewater. Water 2016, 8, 457. [CrossRef]

18. Bôto, M.; Almeida, M.C.; Mucha, P.A. Potential of constructed wetlands for removal of antibiotics from saline aquaculture effluents. Water 2016, 8, 465. [CrossRef]

19. Walton, E.W.; Duguma, D.; Tao, M.; Popko, A.D.; Nygren, S. Integrated mosquito management in experimental constructed wetlands: Efficacy of small-stature macrophytes and fluctuating hydroperiod. Water 2016, 8, 421. [CrossRef]

(C) 2017 by the authors. Licensee MDPI, Basel, Switzerland. This article is an open access article distributed under the terms and conditions of the Creative Commons Attribution (CC BY) license (http://creativecommons.org/licenses/by/4.0/). 